\title{
Effects of Neighboring Countries on the Iraqi Parliament Performance after 2003
}

Ass.Prof.Dr.Omar Jumaa Imran

Political Science College/ Baghdad University

dr_omarjumaa@yahoo.com

Inst. Dr. Ammar Saadoon Albadry

Middle Technical University/Baghdad

Ammartt76@yahoo.com

\subsection{ABSTRACT}

More than ten years after the invasion of Iraq by the U.S force in 2003, the country is still in total shambles. One major factor in this situation is effects of neighboring countries which is considered as an indispensable factor to the political system of Iraq as well as to the effective functioning of the Iraqi parliament. As a result, The study examined how neighboring countries (such as Iran and Turkey) and Arab countries (such as Saudi Arabia and Syria) influence the effectiveness of the Iraqi parliament's during interference in parliamentary elections, support of terrorist operations in Iraq, influence existing laws on foreign affairs and provide financial support to political blocs in the Iraqi parliament that are loyal to these countries especially after the Saddam era. It undertakes an in-depth study of face-to-face interview, parliamentary reports, governmental reports, statutes, laws, and secondary data from academic writings (books, journal articles, and chapters in books) to examine how the influences of neighboring countries affect the Iraqi parliamentary institution functions. The results revealed that parliament was unable to 
perform its functions effectively because of these regional effects.

Keywords: Effects; Neighboring Countries;

Performance; Parliamentary; Iraq

\section{O.2 INTRODUCTION}

Iraq is one of the countries in West Asia that extends to the northwestern end of the Zagros mountain range, the eastern part of the Syrian Desert, and the northern part of the Arabian Desert. Iraq borders Syria to the northwest, Turkey to the north, Iran to the east, Jordan to the southwest, and Kuwait and Saudi Arabia to the south. Iraq has a narrow coastline on the northern Persian Gulf . Figure (1) shows the borders of Iraq and its neighbouring countries.

Figure 1: Map of Iraq and its Neighbour Countries

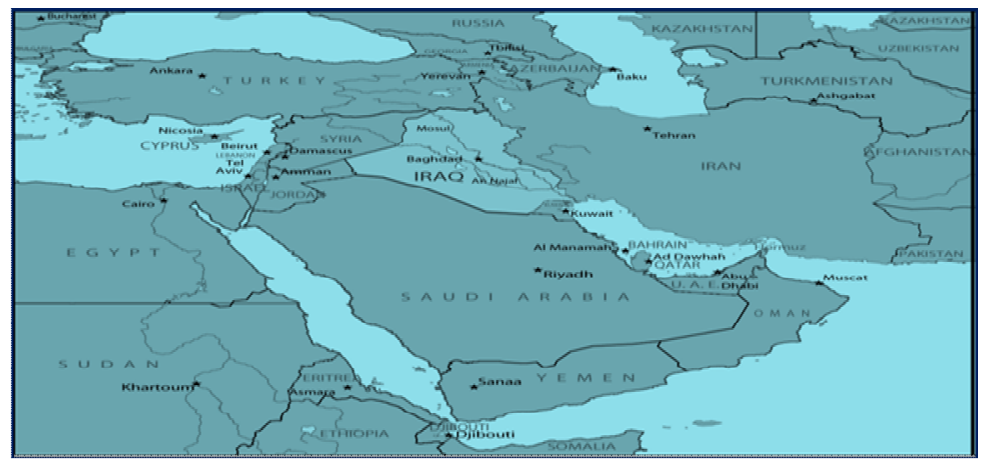

Source: Blanchard et al (2009:7)

These neighbouring countries influenced the political events after the collapse of the Saddam Hussein regime in 2003. The political developments in Iraq had political, economic, and security implications for these neighbouring countries and for the greater part of the Middle East . The instability of Iraq after the fall of the Saddam Hussein regime urged neighbouring countries 
such as Iran, Turkey, Syria, and Saudi Arabia to intervene in Iraqi politics . Neighbouring countries have affected the political process in Iraq by destabilizing the security situation and porous border for terrorists. They have influenced the outcome of elections by providing financial support to parties allied with it, provided support for militias and armed groups, fueled conflict between political parties within the government, sparked sectarian strife among the Iraqi people, which reflected negatively on the legislative and the supervisory process of the Iraqi parliament.

\subsection{STATEMENT OF THE PROBLEM}

The Iraqi parliament is the highest lawmaking body of the country. In addition to its core legislative function of lawmaking, representation and supervision, the parliament is empowered by the constitution to appoint and dismiss the president of the Republic, the Prime Minister, and Ministers, approve budget estimates.In April 2003, Iraq witnessed political transformation after the fall of the Saddam regime. Iraq adopted a parliamentary system in its new constitution of 2005 , instead of the presidential system that has prevailed for more than 35 years. Despite the enormous constitutional role of the new Iraqi parliament in the political system as the immediate representatives of the people, it remains a young institution. Hence, its functional role is still facing criticisms resulting from its weak performance. This negative functional role of the parliament came as a result of a set of external challenges, e.g., the influence of regional neighboring countries (Iran, Turkey, Syria, Saudi Arabia). 


\subsection{RESEARCH INQUIRIES}

This study addresses four main research inquiries. The four research inquiries are on the challenges imposed on some of the regional neighbouring countries (Iran, Turkey, Saudi Arabia, and Syria), faced by the new Iraqi parliament after the end of the Saddam regime in 2004, through their contribution to destabilize the security situation of the country. To answer this inquiry, this study examines and discusses the general assessment of these regional challenges and their impact on the functions of the parliament in the political system of Iraq.Based on these four research inquiries, the research questions are listed below:

1. What is the influence of the Iranian challenges on the functions of the Iraqi parliament after 2003?

2. How did influence the Turkeian challenges on the functions of the Iraqi parliament after 2003?

3. To what extent Saudi Arabia challenges affect the functions of the Iraqi parliament after 2003?

4. What is the influence of the Syrian challenges on the functions of the Iraqi parliament after 2003?

\subsection{RESEARCH METHODOLOGY}

Our study adopts a qualitative research technique with a face-to-face interview approach to elucidate information from the key informants. Some authors argued that the use of qualitative approach would provide better insight in understanding the way people think about issues. The use of the quantitative survey approach for a study of this nature drives dissonant responses (Ahmad \& Seet, 2009:98-104). Therefore, toeing the same line, this study opted for a qualitative research technique with a face-to-face structured interview approach. The need for a face-to-face 
interview is to have first-hand knowledge of the respondents on how neighboring countries affect the effectiveness of the Iraqi parliaments. The essence of the structured questions 1 was to have a clear and apparent focus and call for an explicit answer (Salkind \& Rainwater: 2003). In all, nine people were interviewed comprising of two diplomats, five parliament members and two staff academic. The interviews were conducted once and only for 30 minutes for each interview and these was then transcribed, coded and analyzed to ascertain the extent on which the regional challenges have affected the role of the Iraqi parliament. The Thematic Analysis used in this study because it is considered the most appropriate for any study that seeks to discover using interpretations. It provides a systematic element to data analysis.

\subsection{THE IRANIAN EFFECT}

The relations between Iraq and Iran created tension as observed through some instances of armed confrontation over the past decades. Each party has attempted to expand its control at the expense of the other. For example, during the Ottoman and Iranian regime, Iraq became an arena in which different countries battled one another for control over the Iraqis (Al-Rubaie, 2007: 61).

The Iranian regime was significantly challenged by the U.S. intervention in 2003. Before September 11, 2001, Iran considered Saddam Hussein-ruled Iraq and Taliban-ruled Afghanistan as their nearest enemies. Iran fought against Iraq for eight years and suffered major casualties, including those resulting from chemical warfare. The war ended in 1988 after Iran 
agreed to a ceasefire that signaled their surrender to Iraq. Such loss was partly attributed to the isolation of Iran from the rest of the world (Kemp, 2003: 4).

Accordingly, the interests of Iran over Iraq have been reflected by the long-standing regional ambitions and desires of Iran to resolve its ongoing dispute with the U.S. over the development of nuclear technology and over the Arab-Israeli conflict. After threats of conventional military weapons and weapons of mass destruction (WMD) were removed following the fall of Saddam Hussein in 2003, Iran aimed to prevent Iraq from re-emerging as a threat with or without the presence of U.S. forces. The prevalence of Shiites in Iraq was viewed by Iran as a potential strategic asset that could advance its interests. Therefore, the intentions of Iran over Iraq slightly differed from those of the U.S., which aimed to establish a democratic government in Iraq that could support the interests of the majority and therefore empower potential Shiite allies. The control over Shiite parties, provided Iran with "strategic depth" and ensured the compliance of Iraq with the interests of Iran. The support provided by Iran to many Iraqi Shiite parties and militias prevented the U.S. from promoting stability in Iraq and therefore made Iran a potential threat to the U.S. (Blanchard, 2009: 8).

The overthrow of the regime of Saddam Hussein in 2003 provided the Islamic Republic of Iran with a historic opportunity to transform its relationship with Iraq, formerly one of its most implacable enemies. Iran has used the long, porous border with Iraq, longstanding ties with key Iraqi politicians, parties and armed groups, and its soft power in the economic, 
religious and informational domains to expand its influence and thus establish itself as the key external power broker in Iraq (Eisenstadt et al ,2011: xi).

Iran adopted two strategies to help Iraq free itself from U.S. occupation. First, Iran engaged in direct military confrontations with the U.S. and provided material support to other militias that also resisted the American rule (Al-Ugaili, 2006: 24). Second, Iran increased its political presence by controlling Iraqi political, religious, and military organizations that sought refuge in Iran during the Hussein regime (Researchers Group, 2007:69).

These strategies played a major role in the deterioration of security environment of the parliament and inflamed sectarian strife among politicians, which reflected negatively on the parliamentary institution, which is one of the main bodies of the Iraqi political system. Member of the Iraqi parliament Azhar Abdul Karim Al-Shaykhli argued that the objectives of Iranian policy on Iraq after the regime change in 2003 were achieved by participating in the decision making of the Iraqis and by ensuring that Iran exerts a strong and active influence on the internal affairs of Iraq. She added that Iran presents itself as the regional head of the stability and security arrangements in Iraq and in the Middle East. She concluded that the influence of Iran heightened the preoccupation of the U.S. with Iraqi affairs, through which Iran could avoid being targeted next by the U.S. and other Western nations for its insistence on developing its nuclear programs (Interview, July 5, 2013).

The U.S. has accused Iran of meddling with Iraqi affairs. Iran was one of the first countries that 
recognized the Iraqi Governing Council after its foundation in 2003. Iran also supported the first Iraqi parliamentary elections in 2005 and upheld the results of these elections, which resulted in the victory of the Shiite political blocs and parties that had ties and good relations with Iran. These blocs and parties helped Iran regain its relations with Iraq (Al-Mahdawi, 2006: 298). On the issue of interference by neighbouring countries in the internal affairs of Iraq, Professor of constitutional and political systems Khamis Hezam AlBadri revealed that the political change in Iraq in 2003 was not a result of internal decisions, but external forces. The fear of oppression and cruelty of the Saddam regime caused most leaders and members of the parties in Iraq to flee to neighbouring countries such as Iran, which was against the Saddam Hussein regime. This situation, coupled with the work and the activity of these politicians in Iraq, enhanced their relations with Iran. This was clearly revealed after the change in the regime. All these changes show how Iran has influenced some actors in the political process in Iraq, some of whom even took orders from Iran, as evidenced by their frequent visits to such countries during the crisis. Khamis concluded that Iran disrupted the role of the Iraqi parliament by imposing their will on political settlements of the conflict within Iraq. These countries also imposed its decisions and conditions on the political blocs and pushed political decisions towards a certain direction (Interview, July 6, 2013).

One of the important examples of the strong relations between some Iraqi parties and Iran, was the failure of parliament debates in its session No (2) to reach a 
resolution condemning the daily bombardments of Iranian artillery on villages and border areas of the Kurdistan region of Iraq under the pretext of prosecuting the Kurdistan Workers' Party (PKK) resulting in the death of many citizens. The MPs protested the silence of the Maliki government and his deputies from the Dawa Party, about the Iranian attacks, and demanded the Iranian ambassador to be summoned to the parliament (Minutes of the Iraqi COR, session 2, 2007).

According to professor of constitutional and political systems Hussein Alwan Al-Beige the external challenges reflected by the extensive influence of Iran negatively affected the supervisory and legislative roles of the Iraqi parliament, especially after the announcement of the election results in 2006 and 2010. Al-Beige further revealed that the political polarization of the regional powers, especially Iran have had a decisive influence in determining the form and composition of the government, which was an influential factor in the role and powers of the parliament (Interview, June 3, 2013). E.g., the parliament has postponed its meeting No. 15, because of the outbreak of scuffles between members of the Iraqi List bloc Sunni which demanded the removed of the picture of the commander of the Iranian revolution (Khomeini) from Baghdad streets but members of the National Alliance bloc Shiite rejected these demands. This led to chaos within the parliament and the postponement of the parliamentary session causing many of the laws that were ready to be voted in this session would be passed such as the election law, the civil service law and discussion of the deteriorating 
security situation to be postponed (Minutes of the Iraqi COR, session 15 ,2013).

Some reports have suggested that U.S. military commanders claimed the existence of evidence of attempts by Iran to influence the Iraqi parliamentary election results through financial and military assistance and various proxies in Iraqi politics. Moreover, then-U.S. Secretary of State Clinton, in a hearing before the Senate Foreign Affairs Committee, noted that the U.S. was doing all it could to promote participation in the elections to counteract the effects of Iranian efforts to manipulate the election results through bribery and financial support of candidates (Guzansky, 2011: 90). In response to the same issue, Iraqi Cultural Attaché in Malaysia Hassan Hashim AlSharaa added that the Iranian influence in Iraq was caused product of the "special relations" that linked Iran with a large number of Iraqi politicians from the Shia and the Kurds, who stayed for long periods in Iran when they were opposed to the regime of Saddam Hussein, as well as the weakness of Iraqi politicians and the divisions and conflicts. Such Iranian influence exerted a degree of control on political decisions in Iraq, whether in parliament or the government (Interview, May 12, 2013). Although that the parliament deplored and condemned in its session No (15) in the $4^{\text {th }}$ legislative year,the repeated attacks of the Iranian authorities on the Iraqi fishermen in the Gulf region; the Council called on the government to determine the territorial waters, but this session did not reach positive results in this regard because of the common interests that bound some of the political 
parties and the Iranian government(Minutes of the Iraqi COR, session 15 ,2009).

In the same context, Former Speaker of the Iraqi parliament Mahmoud Al-Mashhadani stated that according to the commander of the American forces in Iraq, U.S. intelligence reports revealed that Iran tried to bribe members of the Iraqi parliament in an attempt to disrupt the bilateral security agreement between Iraq and the U.S., ${ }^{1}$ which stipulated the extension of the U.S. presence in Iraq by one year. He added, "We know that Iran has strong links with a number of Iraqi officials, and I think they take advantage of those relationships to influence the final votes in the COR of Iraq " (interview, June 15, 2013). However, in a parliamentary session attended by 198 deputies out of a total number of 275 members of COR and the parliament approved in its session No. 35 , in the $3^{\text {rd }}$ legislative year by a majority of 144 votes the security agreement with the U.S. deputies of the Sadrist movement led by Shi'ite cleric Moqtada Al-Sadr refused to vote on the security agreement because they believed that this agreement did not serve the interests of the Iraqi people. The Iraqi parliament during several sessions failed to vote on the security agreement with the United States because of the refusal by many of the political blocs. This disrupted the works of the Iraqi parliament (Minutes of the Iraqi COR, session 35, 2008).

\footnotetext{
${ }^{1}$ Iraqi-American Security Agreement is the agreement between the United States of America and the Republic of Iraq on the withdrawal of United States Forces from Iraq and the organization of their activities during their temporary presence in Iraq. This agreement, signed by President George W. Bush in 2008, stipulated that U.S. combat forces would withdraw from Iraqi cities by June 30, 2009, and all U.S. forces will be completely out of Iraq by December 31, 2011 (Bruno, 2008).
} 


\subsection{THE TURKISH EFFECT}

Similar to Iran, Turkey is one of the most influential regional players in the Iraqi politics in two major aspects. The first aspect is the manipulation of official ethnicity, which is done by claiming the protection of Turkmen in Iraq as a reason. This claim caused Turkey to lose historical rights over Mosul-Kirkuk as a result of the British pressure from the resolution league in December 16, 1925, along with the rejection of a Kurdish state in northern Iraq (Siwan, 2008: 350). The second aspect is the attempt of Turkey to control the water sources in its territory (Al-Ugaili, 2006: 18).

The influence of Turkey on the foreign policy of Iraq was clearly shown when Turkey participated in the power struggle under the auspices of the United Nations to protect Iraqi Kurds from Saddam after the 1991 uprising in northern Iraq (Al-Naimi, 2004: 27). At the beginning, Turkey did not support the war waged by the U.S. against Iraq in 2003 because of public pressure. However, on March 21, 2003, the Turkish Parliament permitted Americans to use Turkish aircraft to bomb Iraqi territories and topple Saddam's regime (Mahdawi, 2006: 39).

Turkey faced internal challenges (e.g., PKK) as well as regional challenges (e.g., the presence of Kurds in Iraq and their aspirations for a state of Greater Kurdistan) after the invasion of Iraq in 2003. The initial interest of Turkey was on the development of a political system in Iraq, yet it refused to recognize the Iraqi Interim Governing Council for two reasons. One, this body allowed the Kurds to expand their political influence over the country, and two, the Turkmen were unfairly represented in the Council (Mahdawi, 2006: 177). 
Furthermore, other challenges emerged after the formation of the Iraqi government, in which Kurds secured several important positions (e.g., the presidency, deputy speaker of parliament, minister of foreign affairs, and army chief of staff). Based on such changes, Turkey rejected several Articles of the Iraqi constitution after its official promulgation in December 2005. These Articles included those on federalism and the disputed areas over Kirkuk (e.g., Article 140 of the Constitution on the disputed areas between Arabs and Kurds). In view of this, Turkey continued to interfere in northern Iraq by flying Turkish planes within the aerial territories of Iraq $(20 \mathrm{~km})$ in July 2006, bombarding the Iraqi Kurdish villages near the Turkish border by the Turkish artillery, issuing statements such as those of the Turkish General Staff in June 2006 on the possibility of entry of Turkish troops (more than 140,000 Turkish troops) into northern Iraq, and the decision of the Turkish parliament in October 2007 to allow Turkish troops to enter Iraqi territory and hunt PKK, and so on (Siwan, 2008: 348-375).

The Iraqi political system after the Saddam regime experienced chaos and instability as a result of Turkish intervention in the political decision-making process at the parliamentary and government levels, e.g., the Foreign Relations Committee discussed in parliament session No. 30, the meeting, which brought together the so-called political Council of the Iraqi resistance (a group of former members of the Baath Party) and the American officials under the auspices of Turkey. Where the Council issued a statement of condemnation and denunciation and considered it as interference in Iraqi affairs. The Council asked the Iraqi government to 
summon the ambassadors of the two countries and notify them of the formal protest of the Council. (Minutes of the Iraqi COR, session 30 , 2009). However, the parliament did not reach a satisfactory outcome on this matter.

In the context of this topic 'Member of the legal committee in the Iraqi parliament Hussein Al-Safi stated that the Turkish effect on the Iraqi political process was highlighted after the collapse of the Saddam regime. This influence took on many forms, including intervention in the parliamentary elections by supporting some members of Iraqi Sunni parties pro to Turkey, granting political asylum to MPs and politicians accused of corruption and terrorism, destabilizing the political environment by supporting all forms of terrorism and stirring sectarian strife among politicians, and supporting rebels in neighbouring regions (Interview, July 12, 2013).

A similar view was expressed by Chairman of the Constitution Drafting Committee Humam Hamoudi, who lamented that the role of Turkey in Iraq reflects a clear interference in the internal affairs of the latter, and that this intervention does not deviate from the circle of influence of Turkey on the political parties that were affiliated with it. He stressed that in the 2010 elections, several indicators confirmed the existence of pressure from Turkey to grant the position of Speaker of the House to a member of some of the parties loyal to it. This revelation led to chaos in the parliament because these parties will work for the agenda of Turkish politics instead of the national policy agenda (Interview, July 18, 2013). 
In line with the above responses, the Iraqi Cultural Attaché in Malaysia Hassan Hashim Al-Sharaa argued that the insistence of Turkey to build dams on the Euphrates and Tigris rivers and deprive Iraq of its share of water had a negative impact on arable land in Iraq. He added that in spite of a meeting conducted by several committees in the Iraqi COR, and despite the issuance of several resolutions warning Turkey of the negative effects of these dams on the Iraqi economy, Turkey did not heed these decisions because of its strong influence in Iraq. Consequently, the prestige of the Iraqi parliament as an important institution in the Iraqi political system was tarnished (Interview, May 12, 2013). E.g., the parliament in its session No. 8, discussed the issue of ensuring the quota of water for Iraq from Turkey, and Turkey's attempts to reduce the quota of water (water war) and the Iraqi parliament requested the Turkish government not to reduce the quota that was previously agreed upon., but the parliament failed to reach a positive outcome on this topic (Minutes of the Iraqi COR, session 8, 2009).

In the same context, Former Speaker of the Iraqi parliament Mahmoud Al-Mashhadani expressed that one of the major regional events that affected the functional role of the Iraqi parliament is the bombardment by Turkey of the border areas and the massing of its military forces on the border of the Iraqi Kurdistan region under the pretext of chasing the PKK opposition to Turkey. Although the Iraqi parliament adopted a draft resolution condemning the decision of the Turkish Parliament to allow the government to conduct Turkish military operations inside the Iraqi border to hunt down Kurdish rebels, Turkey continued 
to interfere with the internal affairs of Iraq and violate its territorial integrity (Interview, June 15, 2013).E.g., parliament discussed in its session No. 18 the Turkish shelling of border areas and Turkish military buildup on the Iraqi border of the Kurdistan region of Iraq , and voted on a statement denouncing the Turkish artillery shelling, but parliament was not been able to reach positive results on stopping the Turkish artillery shelling the Kurdistan region because of the positions of some Sunni and Turkmen parties loyal to Turkey as well as the weakness of the foreign policies of the Iraqi government(Minutes of the Iraqi COR, session 18 , 2007).

Apart from the issues described above, the future of the conservative oil-rich Kirkuk presented a major concern for Turkey. Authority over Kirkuk induced a heated dispute between Turkey and Iraqi Kurdistan, in which the former asserted that most residents of Kirkuk province were Turkish citizens. Turkish military leaders threatened the Kurds because of their insistence on the annexation of Kirkuk Province into Iraqi Kurdistan (Ahmed, 2006: 28). The attempts by Turkey to extend its influence over the northern oil fields and trade routes were fueled by historic and economic motives. However, the U.S. asserted that oil from Iraqi territories was the property of the Iraqi people. This statement was probably aimed at dissuading Turkish greed. However, Turkey asserted its wish to promote the interests of Iraqi Turkomans, but in reality, Turkey wanted to influence the Iraqi polity through the Turkoman minority. This support could potentially spill over into support for Turkoman militias (James et al., 2003: 175). 
Professor of constitutional and political systems Hussein Alwan Al-Beige opined that the major aim of the Turkish position on the Kirkuk issue is to prevent Kurdish insurgents, primarily the PKK, from using the Turkish-Iraqi conflict as an opportunity to consolidate their rear areas. The Turkey government feared that Iraqi Kurds might transfer arms or support to the Turkish Kurds, which could encourage the latter to seek autonomy or independence from Turkey. This position was demonstrated during the Iraqi parliamentary elections 2005, in which the position of Turkey government on the results of the elections differed from those of other neighbouring countries. Turkey government believed that the election results unfairly represented various religious groups and failed to reflect Iraqi nationalism; therefore, well-balanced elections, especially in Kirkuk should be demanded (Interview, June 3, 2013).

Journalistic sources indicated that the Turkish Prime Minister "Recep Tayyip Erdogan" and his Foreign Minister "Ahmed Davutoglu" made some an unannounced contacts in Ankara with some heads of Iraqi Sunni parties, especially the head of the united bloc, Osama Najafi, who was the chairman of the parliament and leader of the Islamic Party, Ayad AlSamarrai, the journalistic sources revealed attempts carried out by the Turkish government to unite the political Sunni blocs not to elect the Iraqi Prime Minister Nuri Al-Maliki for the third time. The journalistic sources added that "Ankara can influence all nearby Sunni parties to form a political bloc. It can conduct negotiations with all of Shiites and the Kurds to prevent the third term of the Al-Maliki". The Turkish 
government accuses the Prime Minister Nuri Al-Maliki of following sectarian policies against the Sunnis in Iraq (Asharq Al-Awsat Newspaper, 2014).

\section{O.8 THE SAUDI ARABIA EFFECT}

The relationship between Iraq and Saudi Arabia has been marked by instability. Given that the actions of Iran negatively affected Saudi Arabia, Iraq was financially supported by Saudi Arabia during the first Gulf War (1980 to 1988). However, the relationship between these two countries deteriorated after the Iraqi invasion of Kuwait in 1990. The situation between these countries worsened after Saddam asked Saudi Arabia to cancel the Gulf War debts of Iraq, which amounted to \$12 billion (Luizard, 2006: 219).

Saudi Arabia was wary of the Iraqi regime change in 2003 because the new political forces (Shiite forces) that ruled Iraq differed from those that ruled Saudi Arabia. Nevertheless, Saudi Arabia congratulated the Iraqi government after the $\mathbf{2 0 0 5}$ parliamentary elections. The former viewed the elections as a huge step toward the sovereignty and independence of the country. However, the perception of Saudi Arabia changed when the election results were released and win the Shiite blocs. For instance, the Saudi Foreign Minister during that time, Saud Al Faisal, announced that "Saudi Arabia has the custody of the results of the elections being conducted, the process of which did not include certain segments (Sunni Arab) of Iraq" (Ahmed, 2006: 36).

Iraqi Cultural Attaché in Malaysia Hassan Hashim AlSharaa revealed that Saudi intervention in the political process in Iraq reflected negatively on the performance of the Iraqi parliament through interference in the results of parliamentary elections, supporting some 
members of the Iraqi Sunni parties in the Iraqi government, destabilizing the political environment by supporting terrorism and stirring sectarian strife among politicians, and supporting rebels in Sunni areas of western Iraq. He added that the growing Iranian influence in Iraq, especially after the emergence of the so-called Shiite Crescent ${ }^{2}$, was the real reason that prompted Saudi Arabia to interfere in the political affairs of Iraq. Both Saudi Arabia and Iran were therefore interested in thwarting each other's attempts to gain the widest influence over Iraq. He stressed that the intervention of Saudi was aimed at preventing Iraq from exporting oil to world markets and therefore enabling Saudi Arabia to maintain their monopolistic leadership over the Organization of PetroleumExporting Countries. He added that the intervention of Saudi in Iraq was a result of its concern over the development of a Shiite state in Iran, which could encourage the Shiite minority in Saudi Arabia (approximately $10 \%$ of the total population, and mostly located in eastern oil-rich regions) to claim their rights (Interview, May 12, 2013).

In response to the same issue, Professor of constitutional and political systems Hussein Alwan AlBeige argued that the political system of Saudi Arabia played a major role in spreading chaos and destruction in Iraq, despite its claims to the contrary, causing a negative impact on the performance of the political and

\footnotetext{
${ }^{2}$ The Shia Crescent is a geo-political term used to describe a region of the Middle East where the majority population is Shia Muslim. A region including most of Iran, Iraq, Syria and Lebanon thought to be a destabilizing influence in the Middle East and posing a challenge to the Sunni states (such as Saudi Arabia, Egypt and Jordan). The term was coined by Abdullah II, King of Jordan in 2004, after which it became popular in political debates (Nishapuri, 2011).
} 
parliamentary institutions. Physical evidence confirms this claim, including a 2009 telegram from Christopher Hill, the former U.S. ambassador to Iraq, addressed to the American Congress in which he stressed that Saudi Arabia posed the greatest challenge to Iraqi politicians who were trying to form a stable and independent government. Hill noted that Saudi Arabia held hostile positions against other communities and exerted a strong influence over some places within the region. Hill added that Saudi Arabia was attempting to incite a sectarian conflict in Iraq to destabilize the political process and the Iraqi parliamentary to protect its totalitarian political system from the concept of devolution of power (Interview, June 3, 2013).

At the governmental level، Iraqi Prime Minister Nuri Al-Maliki, in a television interview, accused Saudi Arabia of stimulating terrorist organizations, including al Qaeda of supporting politically and financially. In the media Al-Maliki pointed out that Saudi Arabia waged war on the political system in Iraq by harboring terrorist leaders and Al-Qaeda and extremist groups and recruiting terrorists who came from European countries like Belgium and France. He concluded that Saudi Arabia announced directly the war on Iraq on sectarian and political backgrounds, because they wanted to weaken Iraqi politics in the Arab region (AlMaliki, 2013).

While at the parliamentary level sthe presidency of the Iraqi parliament has remained silent about the document of a U.S. ambassador, Christopher Hill in 2009, which referred to the role of Saudi Arabia in support of terrorism in Iraq, in addition to its role in inciting a sectarian conflict in Iraq to destabilize the 
political process and parliament. It was assumed the presidency of parliament had directed letters to the Union of Arab parliaments, Union of African parliament , Union of European parliament and the UN about the document of ambassador Hill to detect the Saudi role to weaken the Iraqi political system .Iraqi parliament failure to condemn the hostile Saudi foreign policy on Iraq contributed to transform this institution into a political organization dedicated to political conflict and permanently abandon its responsibility in supervision and legislation(The strategic importance of the document of Christover Hall ,2013).

On the other hand, the Los Angeles Times, an American publication, published an article by journalist, Ned Parker about the significant role played by Saudi Arabia in spreading chaos and destructing the Iraqi government, He stated that $45 \%$ of all foreign fighters who attacked American troops, civilians, and Iraqi security forces were from Saudi Arabia, whereas $15 \%$ were from Syria, $15 \%$ from Lebanon, and $10 \%$ from North Africa. Therefore, nearly half of the $\mathbf{1 3 5}$ foreigners detained in Iraq were from Saudi Arabia. In addition, Saudi fighters were believed to be responsible for most of the suicide bombings in Iraq (Hussein, 2007).

Professor of constitutional and political systems Khamis Hezam Al-Badri affirmed that the unstable security situation caused by the terrorist attacks which were Saudi-backed indirectly, contributed to the decline in the performance of the parliament in legislation and supervision. He added that the Saudi foreign policy began to extend its dominance over the Iraqi political system after the Saddam regime by providing material 
and moral support to several armed terrorist organizations in Iraq. Official sources estimated that approximately 2,000 to 3,000 Saudi Arabian troops have been entering the Iraqi territory. Most of these troops were from an organization known as "Jahafil AlTawhid Wal-Jihad fi bilad Al-Rafidain" (Tawhid and Jihad in Mesopotamia). Furthermore, most of the suicide attacks in Iraq were carried out by Saudi Arabian insurgents who filmed themselves before performing terrorist operations (Interview, July 6, 2013).

Iraqi parliament rejected in its session No. 7 , in the $4^{\text {th }}$ legislative year to vote on the agreement to exchange of convicts between Saudi Arabia and Iraq. The Shiite blocs in parliament were justified not to vote on this agreement because of Saudi Arabia's position on Iraq and its support and funding for terrorist operations. In addition to this the Saudis prisoners were accused of terrorism and killers of the Iraqi people. The Iraqi prisoners were just smugglers of sheep or drinks. As the Sunni bloc in the parliament (united list, the Iraqi List) was absent from voting because they saw the need to follow the Iraq foreign policy with Saudi Arabia seriously, and resolve all contentious issues to gain its help in the fight against terrorism in Iraq. At the same time the parliament voted to accept the exchange of convicts Agreement between Iraq and Iran (Minutes of the Iraqi COR, session 7, 2014). Thus it can be concluded that the neighbouring countries had impacts and wide through the support of the pro political blocs to it in the parliament. Thus, reflected negatively on the role of parliament in legislation and control of many of the laws on foreign relations. 
On the sectarian contrast between Iraq and Saudi Arabia and their impact on the political and institutional stability in Iraq, Member of the Legal Committee in the Iraqi Parliament Hussein Al-Safi opined that the expiatory "Fatwa" that were issued by the Wahhabi scholars and approved by the Saudi government called for the demolition of the holy places in Iraq and incited Saudi youth to volunteer to fight the "Shiite" in Iraq. He added that these "Fatwa" have played a significant role in the instability of Iraq and the outbreak of civil war in 2006 between Iraqi communities. Thus the volatile environments in Iraq contributed in foment sectarian conflict between the political blocs in the House of Representatives, which led to weakening its legislative and supervisory role (Interview, July 12, 2013). E.g. although the Iraqi parliament the issue of expiatory "Fatwa" during its session No. 52, in the $2^{\text {nd }}$ legislative year, the parliament failed to yield results on this issue because of the conflicts within the parliament between the Shiite and the Sunni parties that had common interests in Saudi Arabia. In addition, Saudi Arabia did not show any interesting in Iraqi's demands to stop these "Fatwa" (Minutes of the Iraqi COR, session 52, 2007).

In response to the above events, Chairman of the Constitution Drafting Committee Humam Hamoudi asserted that the sectarian hostility between the Iraqi and Saudi governments had a negative impact on the development of relations between the two countries and destabilized the political and parliamentary stability in Iraq because of the Saudi government's attempts to use this sectarian hostility as an essential tool in its foreign 
policy against the Iraqi political system. He added that the relationship of Saudi Arabia with Iraq is not new; it has its historical roots dating back to the establishment of the two states, Saudi Arabia by King Abdulaziz AlSaud, and the modern Iraqi state by King Faisal I. In addition, the "Wahhabi" movement against the Iraqi people was the running ideological doctrine. Motivated by sectarianism, the "Brotherhood" of Wahhabis Bedouins waged brutal attacks and looting on Iraqi cities such as Najaf and Karbala in the last quarter of the nineteenth century. Thousands of inhabitants were killed and the coffers of Shiite holy sites were plundered (Interview, July 18, 2013).

Also, the Iraqi parliament condemned in its session No. 21 , in the $4^{\text {th }}$ legislative year abusive statements made by the Wahhabi cleric in Saudi Arabia, Muhammad AlArifi, against Shiite religious authority, Ayatollah Ali Al-Sistani. The Iraqi parliament called on the Saudi government to take a transparent position on the issue because it was offensive to the religious symbols of Iraq and provoked sectarian conflicts among the people. Saudi Arabia did not show any interest in Iraq's demands to stop these abusive statements. This result reflected the weak role of the parliament in making decisions regarding the countries abusive to Iraq's religious symbols and national issues (Minutes of the Iraqi COR, session 21, 2010).

The reasons for the deterioration of the security and the political of towns in Iraq, especially in Baghdad and the Sunni areas in Mosul and Diyala, Salahuddin were backed by Saudi interference in Iraqi affairs through financial aid that was been distributed by Saudi Arabia to the pro-Iran political parties in Iraq, especially the 
Baathist groups and Al-Qaeda. After the U.S. withdrawal from Iraq in 2011, Saudi Arabia encouraged sectarianism by claiming that the "Sunni" in Iraq risk genocide. Saudi Arabia spent more than USD 75 billion in supporting the secret project called "re-Arab Iraq to an embrace of the Arabs"(The strategic importance of the document of Christover Hall, 2013).

In relation to the assertion above, the Iraqi Ambassador to Malaysia Basim Hattab Toama argued that the Saudi Arabia intervention in supporting terrorism in Iraq had an effect on governmental and parliamentary performance. He stressed that the Saudi regime feared that terrorism that was backed by other countries such as Iran might affect Saudi policy. This concern extended to terrorism in the Iraqi territory and reflected negatively on the security situation in Saudi, as was the case from 2003 to 2007 (Interview, May 16, 2013).

\subsection{THE SYRIAN EFFECT}

The relationship between Iraq and Syria has been characterized by tension, inertia, and competition. After the Baath Party rose to power in both countries (February 8, 1963 in Iraq and March 8, 1963 in Syria), Syria decided to support Iran in the Gulf War against the Iraqi political system. Syria also supported the coalition forces during the second Gulf War in 1991 to expel Iraqi forces from Kuwait. In 1996, Iraq and Syria reached a certain level of reconciliation motivated by economic interests. The flow of Iraqi oil through the Syrian territory to the Port of Banias in Syria, Tripoli, and to Lebanon generated billions of dollars every year 
and led to the signing of numerous trade agreements between the two countries (Hussein, 2010: 99-100).

Syria suffered a huge economic loss after Iraq was invaded by the U.S. in 2003. For instance, Syria lost its control of the Iraqi market, and the flow of Iraqi oil through the Syrian territory was blocked by the U.S. forces in April 2003. Syria was also highly concerned about the desire of the U.S. to change the dictatorship, political regimes in the Middle East region (Sattar, 2008: 199). As a result, Syria sought in its foreign policy towards the Iraqi government after the U.S. occupation of Iraq to strengthen its own influence through thwarting the U.S. project in Iraq and in other MiddleEastern countries .To achieve its own purposes, Syria sought to support terrorism in Iraq as well as support and harbor opponents of the Iraqi Baathist leaders of the former Saddam regime. These policies followed by the Syrian regime contributed to destabilize the security and political stability of the Iraqi regime, therefore this situation reflected negatively on the role and performance of the Iraqi parliament because the parliament was unable to function in an environment where security was unstable.

In line with the above opinions, the chairman of the Iraqi National Congress Ahmed Al-Jalabi confirmed that the growing Syrian influence in Iraq after the U.S. occupation had a negative impact on the performance of the Iraqi political institutions, including the Iraqi parliament. He argued that the Syrian regime played a role in the deterioration of security in Iraq because it served as the main gate through which foreign fighters entered Iraq during the war between March 2003 and April 2003. He adds that based on the statistics from the 
U.S. Army Chief of Staff, Richard Myers, the majority of the foreign fighters that infiltrated Iraq came from Syria. , At least 80 fighters who trained for several months in a Syrian camp before infiltrating Iraq were identified. Ahmed Al-Jalabi added that many leaders and members of the estimated 30,000 to 40,000 members of the Iraqi Baath Party relocated to Syria with the aim of resuming their political activities and preparing themselves against the new political regime in Iraq. The Bashar Al-Assad regime harboured Iraqi operatives and former Baath party officials, and used these groups as leverage in their negotiations with the U.S. and with the Iraqi government over the improvement of the economic relations between the U.S. and Syria, and between Syria and Iraq. He concluded that these strategies in the Syrian foreign policy has had a negative impact on the security environment of the parliament and reduced its role in legislation and supervision. (Interview, July 22, 2013). Syrian foreign policy has been since the beginning of the U.S. occupation of Iraq hostile of the political system in Iraq، e.g. the Syrian stance from the political changes that occurred in Iraq, particularly on the Interim Governing Council that was founded in 2003, was that of reticence. Despite the visits of many Council members to Syria, it viewed this Council as a sectarian body that could not represent the interests of the Iraqi people. Syria believed that the Council was formed by U.S. will and had excluded a considerable number of politicians and political parties (Hameed, 2005: 68).

Although, the Iraqi parliament in its session No. 21, in 2008 condemned the attack by a U.S. military helicopter on Syrian territory, which used the follow-up 
terrorists who had entered Iraqi territory as an excuse. It killed eight people in a strike which the government in Damascus condemned as "serious aggression "and the parliament told the U.S. troops that the Council does not allow any attack from its territory on neighbouring countries. Nevertheless, the Syrian regime continued with its hostile policies against the Iraqi government to destabilize the security and political stability in Iraq (Minutes of the Iraqi COR, session 21, 2008).

On the same issue, member of the Iraqi parliament Azhar Abdul Karim Al-Shaykhli argued that there was a close relationship between the growing influence of the Syrian government based political instability of the Iraqi regime and the weakness of the Iraqi institutions, including the parliament in the performance of its functions .She added that the U.S. presence in Iraq and its policies hostile to the Syrian regime was the main reason for the deterioration of the Syrian-Iraqi relations at that time. She concludes that the Syrian regime's support for the Iraqi resistance and terrorist organizations to fight against U.S. forces had a serious impact on the political stability in Iraq (Interview, July 5, 2013).

In 2009, the Iraqi-Syrian relations witnessed a diplomatic crisis when Maliki accused the Syrian-based Iraq Ba'th Party of plotting a series of devastating bombings in Baghdad. It recalled Iraq's ambassador and demanded that Syria hand over a hundred Iraqi Ba'thists living in Syria, which Syria refused (Hinnebusch, 2014:20).As a result, the Iraqi parliament discussed in its session No. 2, the political crisis between Iraq and Syria resulting from the exchange of 
accusations and tension in the bilateral relations between the two countries. The Council recommended to the Iraqi-Syrian Friendship Committee to improve the atmosphere between the two countries and resolve the crisis diplomatically. However parliament failed to reach a positive result because of the conflict between the political blocs in the Iraqi parliament (Minutes of the Iraqi COR, session 2, 2009).

Before and after Iraq's 2010 parliamentary elections, Syria became a venue for bargaining by rival Iraqi leaders. The leaders of the Iraqiyya bloc, Tariq AlHashimi and Ayad Allawi were the main threat to Prime Minister Nuri Al-Maliki's hold on power (Hinnebusch, 2014:20), but after the National Alliance bloc, headed by al-Maliki won in the election, the Syrian Foreign Minister stated that the Syrian government did not recognize the current government, and Syria was waiting for a new Iraqi government. Parliament in its session No. 21, condemned these statements. Also it did not reach any results, which led to the loss of prestige of parliamentary work, which was a part of the prestige of the Iraqi government(Minutes of the Iraqi COR, session 21, 2010).

The Syrian crisis that resulted from the uprising against the Assad regime in 2011, negatively affected the security situation in Iraq. This effect was engendered by the increase in the smuggling of weapons from Syria to Iraq, and vice versa. These smuggling incidents were made possible by the absence of border patrols on both sides. This rampant smuggling created a favorable environment for Jihadist organizations (e.g., the Islamic State of Iraq and the Levant organization) and allowed such organizations to 
continue their activities and establish their presence within Iraq. The evolution of these Jihadist organizations and the increasing influence of Syria over Iraq contributed to the instability of the political and security systems of Iraq (Haidar, 2012).

Member of the legal committee in the Iraqi parliament Hussein Al-Safi argued that the stance of the members of the Iraqi parliament regarding the Syrian crisis and the divergent views of the various political blocs about such crisis led to large discrepancies, e.g, some MPs sustained the support of the government for the regime of Bashar Al-Assad, whereas others have declared their support for the revolution of the Syrian people, which claimed to adhere to a peaceful manner in obtaining freedom. Al-Safi adda that a sectarian conflict was present within the parliament, particularly between Sunni parties that supported the revolution and the Shiite parties that supported the regime of Bashar AlAssad. This partisan conflict contributed to the weakening of the legislative and supervisory role of the parliament (Interview, July 12, 2013).

By contrast, the Iraqi Cultural Attaché in Malaysia Hassan Hashim Al-Sharaa asserted that the challenges of the neighbouring countries, such as Syria, affected the legislative and supervisory role and functions of the parliament, although the effect was not complete. This effect was a result of intervention of the neighbouring countries in Iraq to ensure its interests. Al-Sharaa adds that the real problem was caused by the Iraqi parliamentarians and politicians themselves and their respective loyalties to the neighbouring countries. He concluded that Iraq has become a main base of the external forces, especially the states that enjoy seeing 
Iraq in conflict and chaos because these conditions can serve their own interests. Furthermore, some regional powers believed that their strength lies in meddling with Iraqi affairs (Interview, May 12, 2013).

In short, external challenges, such as the activities of neighboring countries including Iran, Syria, Turkey and Saudi Arabia, have contributed negatively to the failure of the Iraqi parliament to perform its roles. Moreover, the political violence that emerged from this volatile environment and from the interventions of neighboring countries had a negative impact on the stability of the parliamentary institution and added to the already inadequate performance of Parliament in the number of legislation and control laws during the parliamentary sessions 2006 and 2010 (See Table 1).

\section{Table 1: Achievements of the Iraqi Parliament}

(2006\&2010)

\begin{tabular}{|c|c|c|c|}
\hline $\begin{array}{c}\text { Parliamentary } \\
\text { session }\end{array}$ & Year & $\begin{array}{c}\text { Number of } \\
\text { legislations }\end{array}$ & $\begin{array}{c}\text { Number of officials } \\
\text { interrogations } \\
\text { In parliament }\end{array}$ \\
\hline \multirow{3}{*}{$2006-2010$} & 2007 & 24 & 31 \\
\cline { 2 - 4 } & 2008 & 120 & 15 \\
\cline { 2 - 4 } & 2009 & 110 & 20 \\
\cline { 2 - 4 } & 2010 & 79 & 6 \\
\hline Total & 2011 & 333 & 72 \\
\hline \multirow{2}{*}{$2010-2014$} & 2012 & 117 & 40 \\
\cline { 2 - 4 } & 2013 & 43 & 9 \\
\cline { 2 - 4 } & 2014 & 7 & ----- \\
\hline
\end{tabular}

Source: Parliamentary Office of the Iraqi Council of Representatives (2014) 


\subsection{RESULTS AND DISCUSSION}

The war between the U.S. and Iraq, as well as the policies implemented by the U.S. government in Iraq, resulted in the collapse of the Iraqi state and created a political and security vacuum. Regional and international powers attempted to fill the vacuum by interfering in the internal affairs of the political system in Iraq. However, this situation transformed Iraq into a battle arena where different countries grappled to achieve their interests and expand their influence and control over the political decision of supporting terrorism and the political opposition, buying the loyalty of the political parties, inflaming sectarian conflicts and intervening in the parliamentary and presidential elections .The political violence and deteriorating security situation that emerged from such conflicts negatively affected the stability of the political institutions in Iraq, including the parliament. Therefore, the role and functions of the Iraqi parliament amid the above mentioned external challenges remain substandard.

The data gathered from the study indicated that Iran clearly interfered in Iraqi political decisions. The weakness of the policies pursued by the U.S. during the period of the occupation of Iraq, and the weakness of the Arab regimes played significant roles in the expansion of Iranian influence after the fall of the Saddam regime. Iran's strategic policies based on stirring sectarian might have also affected the ongoing political violence within Iraq after the change of regime. As a result, this violence led to the instability of the security of the parliament, and negatively affected the role and functions of the Iraqi parliament. 
Furthermore, Iran exploited pro-religious parties in Iraq to influence the decisions of the Iraqi parliament and the government.

As for the Turkish effect, and based on the analysis the data of study, the growing Turkish influence in Iraq's foreign policy has had a negative impact on the political system and the parliamentary institution in Iraq. The evolution of the political situation in Iraq and the Kurdistan region had serious repercussions and implications for the Turkish internal and external affairs.Thus made it increase the Turkey intervention in Iraqi affairs further.This influence took on many forms, supporting some members of the Iraqi Sunni parties and Turkmen parties pro to Turkey,intervention in the parliamentary elections,attempts of Turkey to play the role of mediator or provider of an alternative to the Iraqi state and institutions in resolving the internal problems of the Iraqi government,destabilizing the security situation and intervening in the formation of the Iraqi government. This Turkey intervention weakened the parliamentary institution and prevented it from performing its functions because of the lack of political stability and security.In the end, the study found that the Turkey intervention also weakened the Iraqi government, which contributed to the loss of credibility of the parliamentary decisions in terms of strength and effectiveness.

Beside that, data collected from the study evidenced that Saudi Arabia's growing influence in Iraq plays a serious role in disrupting many decisions, both at the government or parliamentary level. This influence became evident after the collapse of the Saddam regime 
through the destabilization of Iraqi security, support for terrorism, encouraging Sunni tribal revolt, interference with the results of the parliamentary elections, and the invitation of Iraqi Sunni leaders to visit Saudi Arabia and discuss the elections and the formation of the government. Saudi intervention in Iraqi politics was a result of the fear of Iranian influence in Iraq, the parliamentary experience, and the devolution of power in Iraq. This Saudi influence in Iraq reflected negatively on the role and functions of the parliament because of the conflict between the Shiite parties that were loyal to Iran and the Sunni parties that were loyal to Saudi Arabia. This situation led to the failure to pass several laws and decisions, including those related to the presidential elections, the formation of the government, and the ratification of some of the conventions pertaining to Iraq and Saudi Arabia, such as the convention on the exchange of prisoners between the two countries, which was signed on June 25, 2013.

Also the study concludes that the emergence of the U.S. as the most influential factor in Iraq created the socalled "new Middle-East", which at present involves the fight against terrorism and other forms of political, social, economic, and cultural rehabilitation of the Middle Eastern societies. All these activities have evidently increased the fear of the neighbouring countries of Iraq including Syria. Unfortunately, however, Iraq has become an open arena for neighboring countries to settle their issues with the U.S., measure their influence within Iraq, and achieve their own interests. In addition, the Syrian influence produced security disruptions that hindered the work 
of the parliament and the government, thereby causing inconsistencies in the positions of political parties regarding the Syrian crisis. Therefore, political conflicts within the parliament negatively affected the performance of the parliament.

Finally, through the previous review of the performance of the Iraqi parliament in the previous parliamentary sessions, the study showed the failure of parliament in the performance of legislative and supervisory duties, as well as failure to respond to the real demands of the Iraqi people. Political reforms can play an important role in improving parliament's performance. Recommendations for these reforms are discussed later.

\subsection{REFERENCES}

Ahmad, NH \& Seet P,( 2009), Dissecting behaviours associated with business failure: A qualitative study of SME owners in Malaysia and Australia. Asian Social Science.;5(9):98- 104.

Ahmed, H.S. (2006). An implication of the U.S military presence in Iraq's neighboring countries. Journal of Palestine studies Center, 26-36.

Al-Badri, K. H. (July 6, 2014).Personal interview. Baghdad, Iraq: Baghdad University.

Al-Beige, H.A. (June 3, 2013). Personal interview. Baghdad, Iraq: Baghdad University.

Al-Mahdawi, M. A. (2006). Iranian policy toward Iraq constitutional. Journal of political Science, Vol. 17 (33), 298.

Al-Maliki: Saudi Arabia and Qatar launches war on the political system in Iraq. (2014, March 8).France 24 News. Retrieved from http://www.france24.com/ar/[Accessed on April 8, 2013].

Al-Mashhadani, M. (June 20, 2014). Personal interview. Baghdad: Iraqi parliament building.

Al-Naimi, A. (2004). Iraqi - Turkish relations: reality and ambition. Journal of Political Science, Vol. 15 (29), 27.

Al-Rubaie, M.K. (2007). The future of Iranian- Iraqi relations.The political and international magazine, Mustansiriya University: Faculty of Political Science, 10, 61.

Al-Safi, H. (July 12, 2013). Personal interview. Baghdad: Iraqi parliament building.

Al-Sharaa, H.H. (2013). Personal interview. Kuala Lumpur, Malysia: Cultural Attaché Building. 
Al-Shaykhli, A. A. (July 5, 2013). Personal interview. Baghdad: Iraqi parliament building.

Blanchard, C. M., Katzman, K., Migdalovitz, C., Prados, A., \& Sharp, J. M (2009). Iraq: Regional Perspectives and U.S. Policy. Washington, DC: Congressional Research Service CRS, 7-8.

Bruno, G. (2008). U.S. Security Agreements and Iraq. New York: the Council on Foreign Relations (CFR).Retrieved fromhttp://www.cfr.org/Iraq/us-security-agreements-Iraq/p16448 [Accessed on Jun 18, 2014].

Eisenstadt, M., Knights, M., \& Ali, A. (2011). Iran's Influence in Iraq: Countering Tehran's Whole-of-government Approach. Washington Institute for Near East Policy, ix.

Ernst and Young Company (2011). Doing business in Iraq. UK: global leader in assurance, tax, transaction, 3.

Guzansky, Y. (2011). 'Made in Iran': The Iranian Involvement in Iraq. Strategic Assessment, Vol. 13(4), 90.

Haidar, R. (2012) "Does the armed conflict to be divided". An-Nahar Newspaper. The Lebanese Center for Research and Consulting.

Hameed ،H.K. (2005). Future of Iraqi - Syrian relations in light of the U.S. occupation of Iraq. Journal of Political Issues, Vol. 9 (10), 68.

Hamoudi, H. (July 18, 2013). Personal interview. Baghdad: Parliament Building.

Hinnebusch, R.(2014). Syria-Iraq relation: State construction and deconstruction and the mena states system. London: LSE Middle East Centre Paper Series.20.

Hussein, A. (2008, November, 18).Iraqi Constitution: problems and solutions. Assabah Newspaper, Retrieved from http://www.abdulkhaliqhussein.nl/index.php?news=159, [Accessed on April 2, 2013].

Hussein، O.F. (2010). Political violence in Iraq after 2003. (Unpublished Master's thesis). Iraq: Baghdad University, 99-100.

Jalabi, A. (July 22, 2013).Personal interview. Baghdad: Parliament Building.

James, D., McGinn, J. G., Crane, K., Jones, S. G., Lal, R., Rathmell, A., \& Anga, R. T. (2003). America's Role in Nation-Building: From Germany to $\operatorname{Iraq}\left(.10^{\text {th ed) }}\right.$.Washington: Rand Corporation, 175.

James, D., McGinn, J. G., Crane, K., Jones, S. G., Lal, R., Rathmell, A., \& Anga, R. T. (2003). America's Role in Nation-Building: From Germany to $\operatorname{Iraq}\left(.10^{\text {th ed) }}\right.$.Washington: Rand Corporation, 175.

Kemp, G. (2003) .Iran and Iraq: The Shia Connection, Soft Power, and the Nuclear Factor. Washington: American Institute of Peace, 4.

Luizard, J, P. (2006). Reducing sectarian to the Iraqi issue. In "The Iraqi society, sociological excavation in ethnicities, sects and classes”. Beirut, Lebanon: publications Institute for Strategic Studies, 219.

Mahdawi, A. M. (2006). Turkish policy toward Iraq after the elections. Journal of Political Science, 33 (17), 39-177. 
Minutes of meetings of the Iraqi Council of Representatives. (2007, 5 September), session (2), $2^{\text {nd }}$ legislative year .Retrieved from http://ar.parliament.iq/LiveWebsites/Arabic/MinutesOfMeetings.aspx - [Accessed on Dec 6, 2011].

Minutes of meetings of the Iraqi Council of Representatives. (2009, November 17), session (15), $4^{\text {th }}$ legislative year .Retrieved from http://ar.parliament.iq/LiveWebsites/Arabic/MinutesOfMeetings.aspx - [Accessed on Nov29, 2011].

Minutes of meetings of the Iraqi Council of Representatives. (2009, July 27), session (30), $4^{\text {th }}$ legislative year .Retrieved from http://ar.parliament.iq/LiveWebsites/Arabic/MinutesOfMeetings.aspx - [Accessed on July 15, 2012].

Minutes of meetings of the Iraqi Council of Representatives. (2009, September 2), session (8), $1^{\text {st }}$ legislative year .Retrieved from http://ar.parliament.iq/LiveWebsites/Arabic/MinutesOfMeetings.aspx - [Accessed on August 20, 2013].

Minutes of meetings of the Iraqi Council of Representatives. (2007, September 21), session (18), 2nd legislative year .Retrieved from http://ar.parliament.iq/LiveWebsites/Arabic/MinutesOfMeetings.aspx . [Accessed on March10, 2011].

Minutes of meetings of the Iraqi Council of Representatives. (2009, September 10), session (2), $4^{\text {th }}$ legislative year .Retrieved from http://ar.parliament.iq/LiveWebsites/Arabic/MinutesOfMeetings.aspx . [Accessed on Dec 18, 2010].

Minutes of meetings of the Iraqi Council of Representatives. (2008, October 28), session (21), $3^{\text {rd }}$ legislative year .Retrieved from http://ar.parliament.iq/LiveWebsites/Arabic/MinutesOfMeetings.aspx . [Accessed on March 12, 2011].

Minutes of meetings of the Iraqi Council of Representatives. (2009, July 29), session (52), $2^{\text {nd }}$ legislative year .Retrieved from http://ar.parliament.iq/LiveWebsites/Arabic/MinutesOfMeetings.aspx - [Accessed on July 25, 2011].

Minutes of meetings of the Iraqi Council of Representatives. (2014, Jan 14), session (7), $\quad 4^{\text {th }} \quad$ legislative year $\quad$.Retrieved fromhttp://ar.parliament.iq/LiveWebsites/Arabic/MinutesOfMeetings .aspx. [Accessed on March19, 2014].

Minutes of meetings of the Iraqi Council of Representatives. (2010, January 23), session (21), $1^{\text {st }}$ legislative year .Retrieved from http://ar.parliament.iq/LiveWebsites/Arabic/MinutesOfMeetings.aspx - [Accessed on Nov 18, 2012].

Nishapuri, A. (2011). Shia Crescent in the Middle East is a good news for Islam, democracy and the West. Pakistan's alternative media (LUBP). Retrieved from https://lubpak.com/about[Accessed on June 19, 2014].

Parliamentary Office of the Iraqi Council of Representatives (2014). Achievements of the Iraqi Council of Representatives in legislative 
sessions 2006 and 2010. (Report, 1-5)Baghdad: Research Department of the Iraqi parliament.

Researchers Group (2007). The dynamics of the conflict in Iraq. Baghdad, Iraq: the Strategic Studies Institute, 69.

Salkind NJ \& Rainwater T,( 2003) Exploring research. Upper Saddle River. Prentice Hall, NJ.

Siwan, H.K. (2008). The Iraqi -Turkish relations, view in the possibility of cooperation and the prospects of conflict. In "Iraq under occupation, the destruction of the state and the consecration of chaos". $A l$ Mustaqbal Al Arabi Journal, 60, 348-375.

The strategic importance of the document of Christover Hall (2013, 26 August). The involvement of Saudi Arabia of supporting terrorist operations in Iraq. Baghdad: Buratha News Agency. Retrieved from http://ns1.bah2day.com/news/208360.html[Accessed on August 28 2013].

Toama, B.H. (May 16, 2013). Personal interview. Kuala Lumpur, Malaysia: Iraqi Embassy.

Turkey intervening the internal affairs of Iraq and are able to influence the Najafi and Samurai.(2014,Wednesday June 4). Asharq Al-Awsat Newspaper , Retrieved from http://www.aawsat.net/ [Accessed on June 15, 2014]. 